\title{
Duplication of the southern white rhinoceros (Ceratotherium simum simum) luteinizing hormone $\beta$ subunit gene
}

\section{A Lund and G B Sherman}

Department of Veterinary Biosciences, College of Veterinary Medicine, University of Illinois, 2001 South Lincoln Avenue, Urbana, Illinois 61802, USA

(Requests for offprints should be addressed to G B Sherman who is now at University of Nebraska-Lincoln, Great Plains Veterinary Educational Center, PO Box 187, Clay Center, Nebraska 68933, USA)

\begin{abstract}
Luteotropic glycoprotein hormones (LGH) include luteinizing hormone (LH) and chorionic gonadotropin $(\mathrm{CG})$. The order Primates is the only phylogenetic clad known to exhibit more than one LGH $\beta$ subunit gene per haploid genome. In the present study, we report the discovery of a second case of LGH $\beta$ gene replication, in the white (w) rhinoceros ( $\mathrm{r}$ or rhino). The presence of more than one gene was strongly suggested by a complex banding pattern observed on Southern blots of DNA prepared from two unrelated white rhinos. The existence of two LGH $\beta$ genes per haploid genome was estimated by genomic equivalence assay. However, genomic restriction-site mapping studies, together with other findings, suggested that the replicates are probably not tandemly arranged as occurs in primates. A simple band pattern was observed in Southern blots of four other perissodactyl species, indicating that a single-copy LH $\beta$ gene is the consensus condition. Two distinct white rhino $L H \beta$ genomic clones (wrLH $\beta 1$ and wrLH $\beta 2$ ) were isolated. The nucleotide sequence of wrLH $\beta 1$ was identical with that of wrLH $\beta 2$, except that the
\end{abstract}

latter lacked the consensus mammalian LGH $\beta$ second intron. Sequences of the TATA-containing proximal 5 '-flanking regions of the two genes were homologous to at least -57 relative to the site of pituitary transcriptional initiation. We conclude that wrLH $\beta 1$ is the extant form of the ancestral perissodactyl LH $\beta$ gene, whereas wrLH $\beta 2$ is a randomly integrated cDNA element (processed gene) reverse transcribed from a partially spliced ancestral wrLH $\beta 1$ mRNA. That wrLH $\beta 2$ was heritable demonstrates that wrLH $\beta 1$ was transcribed in gametes or early conceptus cells contributing to the germline at some point in time since the divergence of white rhinos from other members of the family Rhinocerotidae. Furthermore, because homologous proximal (pituitary) promoter sequence is present in wrLH $\beta 2$, it can be concluded that the wrLH $\beta 1 \mathrm{mRNA}$ template from which wrLH $\beta 2$ is derived was transcribed from a secondary promoter located upstream of the consensus TATA-regulated pituitary promoter. Fournal of Molecular Endocrinology (1998) 21, 19-30

\section{INTRODUCTION}

There are two types of mammalian luteotropic glycoprotein hormones (LGH), luteinizing hormone $(\mathrm{LH})$, produced by gonadotropes in the anterior pituitary gland, and chorionic gonadotropin (CG), produced by trophoblasts within the placenta. Pituitary expression of LH is ubiquitous among mammals, while placental CG expression is well described only in equids and primates (Pierce \& Parsons 1981). LH plays an essential role in the endocrine regulation of gamete development in mammalian testes and ovaries, whereas $\mathrm{CG}$ is postulated to support ovarian function during pregnancy. Despite differences in their tissue sources, secretory patterns and the reproductive periods during which they function, $\mathrm{LH}$ and $\mathrm{CG}$ are classified together as luteotropic gonadotropins because they bind to the same $\mathrm{LH} / \mathrm{CG}$ gonadal receptor and induce similar luteotropic responses. Moreover, these two gonadotropins are biochemically related, each containing a common $\alpha$ subunit 
non-covalently bound to a hormone-specific $\beta$ subunit, a heterodimeric structure required for high-affinity receptor binding and induction of biological activity (Bousfield et al. 1994). Similarity is high $(>95 \%)$ between $\operatorname{LH} \beta$ and CG $\beta$ gene sequences, reflecting the fact that they evolved from a common ancestral LH $\beta$ gene (Talmadge et al. 1984).

In the haploid genomes of most mammals, an LH $\beta$ gene is present as a single copy, directs pituitary-limited TATA-driven transcription of an mRNA with a short (6-11 nucleotide) $5^{\prime}$ untranslated region (UTR), and encodes a mature peptide of 121 amino acids (Bousfield et al. 1994). These consensus LH $\beta$ gene and locus attributes are postulated to represent the ancestral mammalian condition. By contrast, different structural and functional features are evident at LGH $\beta$ loci within the order Primates and the family Equidae, the two lineages known to produce both $\mathrm{LH}$ and CG.

In equids, there is an LH/CG $\beta$ gene that is present as a single copy (Sherman et al. 1992) which has gained the capacity for placenta-specific as well as pituitary-specific expression (Murphy \& Martinuk 1991, Sherman et al. 1992). This is in contrast with primates in which a single pituitaryspecific $\mathrm{LH} \beta$ gene is linked to a cluster of six CG $\beta$ genes. While some primate $\mathrm{CG} \beta$ replicates may be pseudogenes, those that are functional are expressed in a placenta-specific manner (Bo \& Boime 1992). In the horse, LH/CG $\beta$ gene transcription is TATAdriven in both pituitary and placenta (endometrial cup). However, the presence of tandemly repeated functional TATA elements within a distinctive $51 \mathrm{bp}$ insert in the horse leads to synthesis in both tissues of mRNAs with elongated $5^{\prime}$-UTRs (Sherman et al. 1992). By comparison, pituitary $\mathrm{LH} \beta$ gene expression in primates is directed by a consensus single-TATA promoter, whereas functional CG $\beta$ genes adopt an alternative TATA-less upstream promoter to drive placental-specific expression. Thus, in both equids and primates, modifications of proximal promoter usage and $5^{\prime}$-UTR length and/or sequence structure correlate with acquisition of the capacity for placental expression.

CG expression is widespread throughout the order Primates (Crawford et al. 1986, Gwenda et al. 1990, Hearn et al. 1991, Steinetz et al. 1992, Seshagiri \& Hearn 1993, Summers et al. 1993). However, it is not known whether placental CG expression is similarly widespread within the order Perissodactyla, which is composed of three extant families, Equidae, Rhinocerotidae and Tapiridae. By virtue of their relatively close phylogenetic relationship to equids, non-equid perissodactyl species represent a potentially valuable comparative genetic model for the study of the evolutionary pathways and molecular events associated with transition from pituitary-limited LH $\beta$ gene expression (consensus mammalian condition) to the dual pituitary/placental expression capacity of the equid $\mathrm{LH} / \mathrm{CG} \beta$ gene. We have previously found preliminary evidence that some rhinoceros species exhibit pituitary $\mathrm{LH} \beta \mathrm{cDNA} / \mathrm{mRNA}$ features similar to the consensus mammalian pituitary transcript (Sherman et al. 1997). In the present study, the objective was to further describe the perissodactyl LGH $\beta$ locus by determining gene copy number for several perissodactyl species and by isolating and characterizing the nucleotide sequence of the first LGH $\beta$ genomic clones from a rhinoceros species.

\section{MATERIALS AND METHODS}

\section{Animals}

Tissue samples were collected from five perissodactyl species including Sumatran rhino (Dicerorhinus sumatrensis), Indian rhino (Rhinoceros unicornis), black rhino (Diceros bicornis), southern white rhino (Ceratotherium simum simum), and Baird's tapir (Tapirus bairdii). Samples were obtained from two unrelated southern white rhinos; one was a captive 31-year-old female in residence at the Fossil Rim Wildlife Refuge, Texas (white rhino 1), and the other was a 5-year-old male from Matobo National Park in Zimbabwe (white rhino 2).

\section{PCR amplification and sequence analysis}

White rhino LH $\beta$ (wrLH $\beta$ ) sequence amplifications were performed in a total volume of $100 \mu$ l using the Perkin-Elmer DNA Thermal Cycler (Norwalk, CT, USA) and $1 \mu \mathrm{g}$ genomic DNA as target. (Primer locations are shown in Fig. 2.) Except where noted, biochemicals were purchased from Gibco-BRL (Grand Island, NY, USA). White rhino $2 \mathrm{LH} \beta 1$ and $\mathrm{LH} \beta 2$ sequences were amplified using a consensus mammalian LGH $\beta$ forward primer P-3 (5'-GGCCTTGCCGCCCCCACA) and a white rhino-based (Sherman et al. 1997) reverse primer P-2 (5'-ACGGTTCGAGATG CCTTTAT) with the Perkin-Elmer GeneAmp XL PCR Kit in reactions containing $2 \mathrm{U} / 100 \mu \mathrm{l}$ Tth polymerase, $200 \mu \mathrm{M}$ deoxynucleotide triphosphates, $0.25 \mu \mathrm{M}$ primers and $1.5 \mathrm{mM}$ magnesium acetate. PCR was carried out for 33 cycles (denaturation at $95{ }^{\circ} \mathrm{C}$ for $1 \mathrm{~min}$; annealing at $64^{\circ} \mathrm{C}$ for $1 \mathrm{~min}$; extension at $72{ }^{\circ} \mathrm{C}$ for $2 \mathrm{~min}$ ). An Indian rhinobased primer (P-1; 5'-GCCTGCAGGTATAAG ACCAGGTAA ACA) located immediately 
downstream from P-3 was used with P-2 to amplify white rhino $1 \mathrm{LH} \beta 2$ sequence. Final PCR reagent concentrations were: $200 \mu \mathrm{M}$ deoxynucleoside triphosphates, $0 \cdot 25 \mu \mathrm{M}$ primers, $10 \mathrm{mM}$ Tris, $\mathrm{pH} 8 \cdot 3$, $50 \mathrm{mM} \mathrm{KCl}, 1.5 \mathrm{mM} \mathrm{MgCl}_{2}, 0.001 \%$ gelatin and $2.5 \mathrm{U} / 100 \mu \mathrm{l}$ Taq polymerase (Gibco-BRL). The reaction was performed as above with the exception of a $59{ }^{\circ} \mathrm{C}$ annealing temperature. Another PCR was conducted using as target BamHI-digested white rhino 2 genomic DNA gel, isolated from an approximately $2500 \mathrm{bp}$ band that hybridized with wrLH $\beta$ cDNA probe. PCR was carried out for 33 cycles (denaturation at $95^{\circ} \mathrm{C}$ for $1 \mathrm{~min}$; annealing and extension at $72{ }^{\circ} \mathrm{C}$ for $2.5 \mathrm{~min}$ ) using the reagents as specified above for the Taq polymerase and white rhino-based primers P-6 (5'TGCCCCGTCTGCATCACCTTCAC) and P-7 (5'-CGGGAGCCGGATGGAGGCAA). The resulting $450 \mathrm{bp}$ product was subsequently used as template in a semi-nested PCR employing a degenerate consensus mammalian primer (5'ACCA(C/G)CATCTG(C/T)GCCGGCTACTG $(\mathrm{C} / \mathrm{T}) \mathrm{CC}(\mathrm{C} / \mathrm{T}) \mathrm{A}(\mathrm{C} / \mathrm{G}) \mathrm{ATG})$ complementary to the final $33 \mathrm{bp}$ of LGH $\beta$ exon 2 paired with P-7. Sequence analysis of a $425 \mathrm{bp}$ product revealed the first $66 \mathrm{bp}$ of wrLH $\beta$ exon 3 at the $3^{\prime}$ end of the fragment, indicating that the remaining sequence contained LH $\beta$ intron 2 (data not shown). PCR was carried out for 33 cycles (denaturation at $95{ }^{\circ} \mathrm{C}$ for $1 \mathrm{~min}$; annealing at $63{ }^{\circ} \mathrm{C}$ for $1 \mathrm{~min}$; extension at $72{ }^{\circ} \mathrm{C}$ for $2 \mathrm{~min}$ ) using the reagents as specified above for the Taq polymerase.

After cloning into pCR-Script (Stratagene, La Jolla, CA, USA), amplification products were sequenced in both directions using an Applied Biosystems 373A Automated DNA Sequencer (PE Applied Biosystems, Foster City, CA, USA). (Sequencing primer locations are shown in Fig. 2 for the principal full-length cloned PCR products). Vector-based primers include P-F (5'-GTAAAAC GACGGCCAGT), P-R (5'-AGCGGATAACAA TTTCACACAGGA) and P-KS (5'-TCGAGGTC GACGGTATC). Primers based on LGH $\beta$ sequence include P-4 (5'-GTGTGCACCTACCA TGA), P-21 (5'-ACCACCAGCATCTGTGCCG GCTACTG) and P-5 (5'-TGGGCCGGCACAGT GGCCGCAGTGG).

\section{Genomic Southern blots}

Tissues used for genomic DNA isolation included liver (Sumatran rhino and white rhino 1), testes (Indian rhino and tapir) and pituitary (black rhino, white rhino 1 and white rhino 2). DNA was prepared by proteinase $\mathrm{K}$ digestion and organic extraction using standard techniques (Strauss 1995).
Biochemicals and restriction enzymes were purchased from Gibco-BRL. A $10 \mu \mathrm{g}$ sample of restriction enzyme-digested DNA was electrophoresed in a $0.7 \%$ agarose gel prepared using TBE buffer $(89 \mathrm{mM}$ Tris, $89 \mathrm{mM}$ borate, $2.76 \mathrm{mM}$ EDTA, $\mathrm{pH} 8 \cdot 3$ ) at $2.5 \mathrm{~V} / \mathrm{cm}$ for $8-11 \mathrm{~h}$. Gels were prepared for blotting on to Duralon-UV membrane (Stratagene) according to the manufacturer's specifications and DNA was transferred by standard capillary blotting (Brown 1995). Blots were hybridized to ${ }^{32} \mathrm{P}$-labeled probe prepared by randomprimed labeling (Multiprime DNA Labeling System; Amersham, Arlington Heights, IL, USA) for $2.5 \mathrm{~h}$ at $65^{\circ} \mathrm{C}$ in QuikHyb solution (Stratagene). Two washes in $2 \times \mathrm{SSC} / 0 \cdot 1 \% \operatorname{SDS}$ at $25^{\circ} \mathrm{C}$ for $15 \mathrm{~min}$ were followed by a final wash in $0 \cdot 1 \times \mathrm{SSC} /$ $1 \% \mathrm{SDS}$ at $60{ }^{\circ} \mathrm{C}$ for $30 \mathrm{~min}$. (Single-strength SSC is $0.15 \mathrm{M} \mathrm{NaCl}$ and $0.015 \mathrm{M}$ sodium citrate.) Membranes were exposed to autoradiography film (X-OMAT AR; Eastman Kodak, Rochester, NY, USA) with an intensifying screen at $-70{ }^{\circ} \mathrm{C}$ for 30-48 h.

DNA used for probe synthesis included wrLH $\beta$ cDNA sequence corresponding to codons -20 to +121 (Sherman et al. 1997), and a fragment comprising the first $220 \mathrm{bp}$ of wrLH $\beta 1$ intron 2 . The latter was a restriction digested product of a larger amplification product that spanned intron 2 and included the first $66 \mathrm{bp}$ of exon 3 (see PCR methods above). The intron 2 fragment was used as a probe to identify bands containing only wrLH $\beta 1$ sequence, while wrLH $\beta$ cDNA probe, which could hybridize to both wrLH $\beta 1$ and wrLH $\beta 2$, was used for all other Southern blots.

To perform genomic titration analysis, plasmid containing wrLH $\beta 1$ PCR product was digested to release a $3450 \mathrm{bp}$ fragment containing full-length wrLH $\beta 1$ sequence flanked by plasmid sequence. Aliquots of the digest containing 1, 2 or 3 genomic equivalents were added to $10 \mu \mathrm{g}$ white rhino genomic DNA digested with either HindIII or BamHI and then subjected to standard Southern blotting procedures. The number of genomic equivalents present in $10 \mu \mathrm{g}$ white rhino genomic DNA was calculated from an estimated value of $3.0 \times 10^{9} \mathrm{bp}$ per haploid mammalian genome (Lewin 1997a). Densitometric analysis (total optical density in a constant area) was performed using the PDI Discovery Series densitometry system running RFLPrint software (PDI, Huntington Station, NY, USA).

\section{RESULTS}

To determine whether there are one or multiple wrLGH $\beta$ genes per haploid genome, Southern blot 

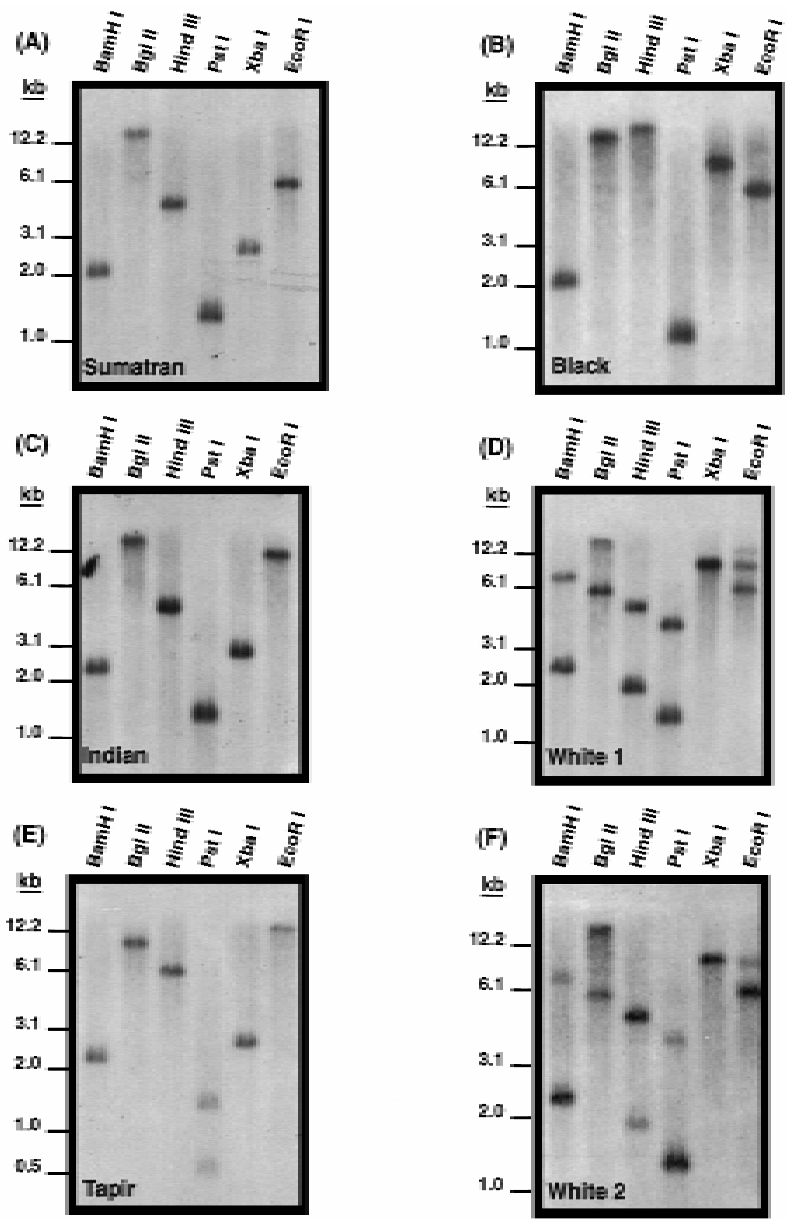

FIGURE 1. Southern blots of genomic DNA isolated from four rhinoceros species and one tapir species. Blots were hybridized with full-length wrLH $\beta$ cDNA probe. The simple banding pattern observed for Sumatran, black and Indian rhinos $(\mathrm{A}-\mathrm{C})$ and Baird's tapir (E) strongly suggests a single-copy LH $\beta$ gene per haploid genome. By contrast, the predominance of lanes with multiple bands for two unrelated white rhinos (D and F) indicates the presence of two or more LGH $\beta$ genes in this species.

analyses of restriction enzyme-digested white rhino, black rhino, Sumatran rhino, Indian rhino and Baird's tapir genomic DNA were performed (Javan rhino tissue was unavailable). All species except the white rhino exhibited a simple banding pattern (generally a single band per lane; Fig. 1), strongly suggesting a single-copy gene. By contrast, two bands were observed in most lanes for the white rhino (Fig. 1D). To confirm that this more complex banding pattern was not unique to the original white rhino subject being evaluated (white rhino 1), genomic DNA was prepared from an unrelated white rhino (white rhino 2) and assayed in the same manner. The complex Southern banding pattern was again observed (Fig. 1F). The presence of multiple bands in a majority of the white rhino lanes supports the contention that there are two or more LGH $\beta$ gene copies per haploid genome in this species.

Homologous primers based on wrLH $\beta$ cDNA sequence were used with consensus mammalian LGH $\beta$ primers to amplify full-length wrLH $\beta$ gene fragments. Two major amplification products of different size were generated (Fig. 2). One of the amplified fragments (wrLH $\beta 1$ ) was of the expected size $(\sim 1260 \mathrm{bp})$, whereas the other amplified fragment (wrLH $\beta 2)$ was smaller $(\sim 960 \mathrm{bp})$ than predicted for a typical mammalian LGH $\beta$ gene (Fig. 2A). Putative coding sequence regions of wrLH $\beta 1$ and wrLH $\beta 2$ clones (Fig. 2B) were identical, differing at only two nucleotide positions from pituitary-derived wrLH $\beta$ cDNA sequence previously characterized in our laboratory (Sherman et al. 1997). One substitution constituted a silent mutation $\left(\mathrm{Arg}^{112}\right)$, while the other encoded $\mathrm{Arg}^{2}$ in the gene and $\mathrm{Lys}^{2}$ in the cDNA. As in the cDNA, (1) all cysteine residues were found to be in register with the 14 highly conserved cysteines present in the consensus mammalian LH $\beta$ subunit (Bousfield et al. 1994), (2) a single consensus glycosylation attachment site was present at $\mathrm{Asn}^{13}$, which is the typical location for oligosaccharide attachment in other mammalian LH $\beta$ subunits (Bousfield et al. 1994), and (3) the in-frame translational stop codons for wrLH $\beta 1$ and wrLH $\beta 2$ defined amino acid position +121 as the $\mathrm{C}$-terminus, demonstrating that neither wrLH $\beta$ gene encodes the C-terminal peptide extension (CTP) which is present on both equid LH/CG $\beta$ and human CG $\beta$. Thus, the common wrLH $\beta 1 /$ wrLH $\beta 2$ coding sequence suggests a consensus LH $\beta$ peptide structure (Bousfield et al. 1994). (Although the use of the term wrLGH $\beta$ would acknowledge uncertainty about the tissuespecific expression patterns, these genes are designated wrLH $\beta$ here to adhere to convention.)

Unlike the coding sequence regions, there was a salient intronic sequence difference between the two wrLH $\beta$ genes. While wrLH $\beta 1$ exhibited an exon-intron structure typical of the consensus mammalian LH $\beta$ condition (three exons and two introns), wrLH $\beta 2$ was missing the $289 \mathrm{bp}$ consensus second intron (Fig. 2). The resulting wrLH $\beta 2$ gene was structured such that exons 2 and 3 were perfectly conjoined, preserving the correct reading frame. Accordingly, if expressed, the wrLH $\beta 2$ gene would contain two exons and one intron. By contrast, consensus first introns were present in both wrLH $\beta$ genes and their nucleotide sequences were identical. To ensure that the absence of the 
(A) wrLHB1
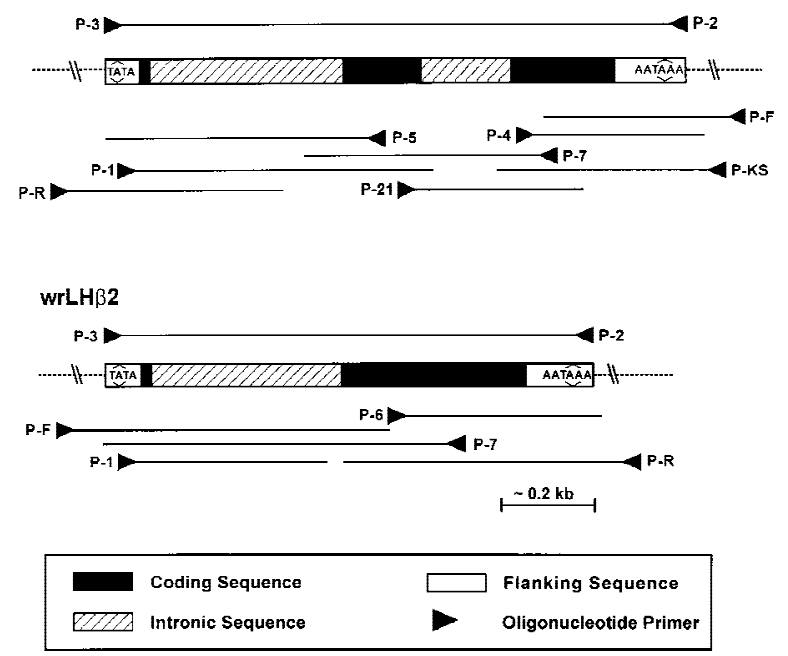

(B)

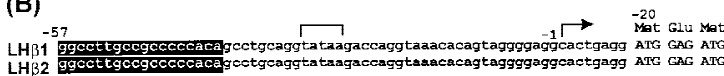

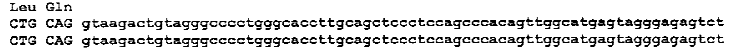

tgtgacctggtgaaggaggectetttotccacggtgtggacagocagcaggettcetgecaggaggagggaagtgggta tgtgacc tggtgaaggaggectetttctccacggtgtggacagecagcaggettcctgecaggaggagggaagtgggta

ggaca tggectgaygeggecttetgaggtgttgcggttatctgggg tcectgggtgacaggatgggggatcanagtgga ggaca tggcetgagggggcet tetgaggtgt tgeggt tatetggggtcectgggtgacaggat ggggga tcaaagtgg

ggggtgggccctgat ggaaga tgtcagetgggtcectgaa tgtgtgta tg tgggggctgggagggtgagggcecaggg ggggtgggece tgat

$$
\text { Gly Leu Leu Leu TrP Leu }
$$

-10 Lau Lau Ser

agagg tctcaggetggcectgaggeactggecttgtecesg GGG CTG CTG CTG TGG CTG CTG CTG AGC
agaggtetcaggetggcectgaggeactggecttgteceag GGS CTG CTG CTG TGG CTG CTE CTG AGC

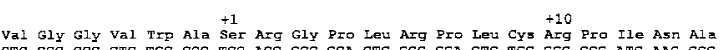

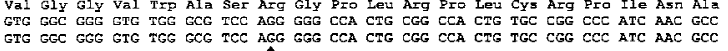

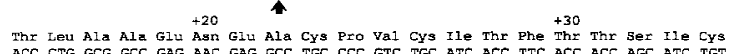

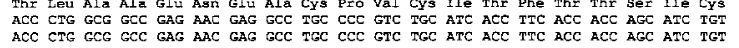
Ala Gly TYr CYs Pro +40

Ala Gly TYr CYs Pro Ser Met
GCC GGC TAC TSC CCC AGC ATG
GCC GGC TAC TGC CCC AGC ATG $\ldots \ldots \ldots \ldots \ldots \ldots \ldots \ldots \ldots \ldots \ldots \ldots \ldots \ldots \ldots \ldots \ldots \ldots \ldots \ldots \ldots$

ctgccacotetgctcoaggtggatggctcagggcaggcceacagaagacgggagg tggcagogggggtggaagggtgg

cctgccecetggggcaggggctggggaattggagteagagctgggcgtgtgggggaacacagggtecectggacace

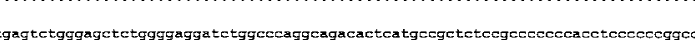

tgagtetgggagctetggggaggatetggeecaggengacacteatgeegetetecgeesceceacetececesggeo

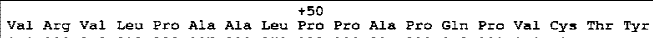

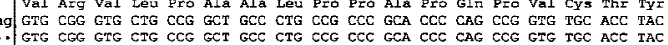

+60
His Glu Leu Arg phe Ala ser Ile Arg Leu Pro Gly CYs Pro Pro GlY Val Asp Pro Met CAT EAG CTG CGC TTT GCC TCC ATC CGG CIC CCG GGC TGC CCG CCT GGT GTG GAC CCG AT
CAT GAG CTG CGC TTT GCC TCC ATC CGG CIC CCG GGC TGC CCG CCT GGT GTG GAC CCG ATG

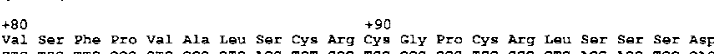

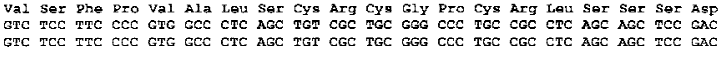
$+100$

Cys Gly Gly Pro Arg ala Gln Pro Leu Ala Cys Asp Arg Pro pro Leu pro gly Leu Le TGC GGG GGT CCC AGG GCC CAG CCC TTG GCC TGT GAC GGG CCC CCA CTC CCA GGC CIC CTC +120
phe Leu Ter

TTC CTC TAA ggatcceccaccecaacttcccaggeceacctccactcetggagccagcagacgctcetcecctec

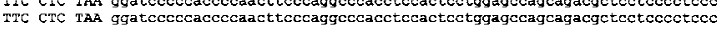

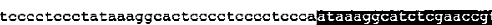

second intron was not an artefact, additional amplification reactions were carried out using white rhino genomic DNA as template. Fragments containing and lacking second intron sequence were routinely amplified, confirming the existence of both intron-containing and intronless wrLH $\beta$ target (data not shown). An amplified Indian rhino LH $\beta$ genomic fragment corresponding to amino acid position -20 to codon +70 of the third exon was also isolated and sequenced to determine whether a second intron was present in a rhino species known to exhibit a single-copy LH $\beta$ gene. Like wrLH $\beta 1$, this fragment contained the consensus second intron (data not shown).

Homology between the two genes included $65 \mathrm{bp}$ of $5^{\prime}$-flanking sequence (Fig. 2B) extending from the beginning of the cloned inserts to the putative translational start codon. Similarly, 100\% sequence identity was observed over the $103 \mathrm{bp}$ span of 3 '-UTR sequence included in the genomic clones (Fig. 2B). There was, however, a $25 \mathrm{bp}$ deletion in the $3^{\prime}$-UTR of the cDNA compared with the genes. This deletion is presumably a consequence of a cDNA amplification artefact, alternative splicing during transcriptional termination, or the existence of an alternative wrLH $\beta$ allele. Other features of the two genes, including relative locations of TATA elements, polyadenylation signals, and intron-exon structure in the region of the first intron, were

FIGURE 2. (A) White rhinoceros LH 31 and LH $\beta 2$ gene amplification and sequencing strategies. Triangles represent primers used for PCR or sequencing. Lines extending from triangles depict full-length PCR-amplified fragments generated from pairs of primers (above gene diagram) or sequence obtained using a given primer (below gene diagram).

(B) Nucleotide and deduced amino acid sequences of two wrLH $\beta$ genes (LH $\beta 1$ and $L H \beta 2)$. The sequence of wrLH $\beta 1$ reflects consensus LH $\beta$ gene features, whereas wrLH $\beta 2$ lacks the second intron (dots within boxed area) but otherwise shares perfect sequence identity with wrLH $\beta 1$. Numbers directly above the amino acid sequence indicate codon position relative to the first residue of the mature peptide. Numbers directly above the nucleotide sequence (first line) and in the right margin indicate nucleotide position relative to pituitary transcriptional initiation (right-angled arrow). Arrowheads denote base differences relative to pituitary-derived wrLH $\beta$ cDNA which contained adenine at both positions. Brackets indicate consensus TATA elements and polyadenylation signal sequences. Reverse-type designates homologous, but not necessarily wild-type, wrLH $\beta$ sequence corresponding to consensus ungulate amplification primers. GenBank accession numbers for wrLH $\beta 1$ and wrLH $\beta 2$ are AF024520 and AF024521 respectively. 


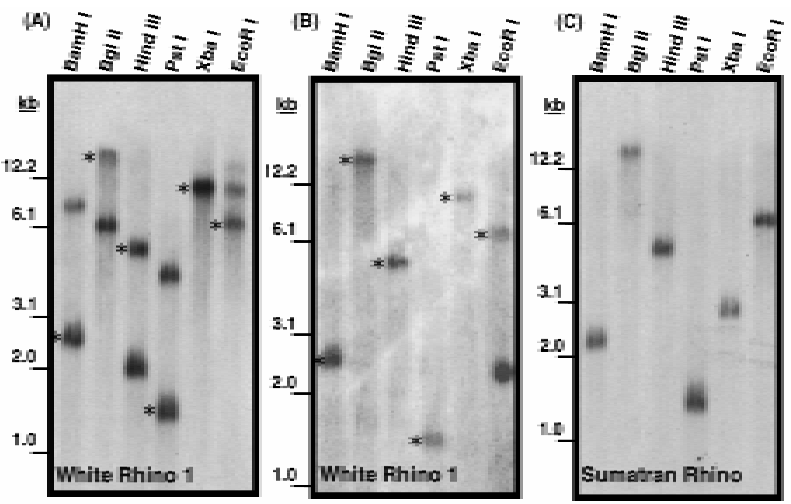

FIGURE 3. Gene-specific Southern blots. The complex white rhino Southern banding pattern observed with full-length wrLH $\beta$ cDNA probe $(\mathrm{A})$ was reduced to a single band-per-lane pattern with wrLH $\beta 1$-specific second intron probe (B). Asterisks indicate corresponding wrLH $\beta 1$ bands. The high degree of similarity between probe-positive restriction fragment lengths observed in the side-by-side comparison of the intron-hybridized blot (B) and the blot of a rhino species known to carry a single-copy LH $\beta$ gene $(\mathrm{C}$; hybridized with the same probe) suggests that wrLH $\beta 1$ corresponds to the ancestral single-copy perissodactyl $\mathrm{LH} \beta$ gene.

consistent with consensus mammalian LH $\beta$ gene structure.

Second intron sequence was isolated, labeled, and used to probe white rhino genomic Southern blots to identify which of the bands in each lane corresponded to wrLH $\beta 1$ (Fig. 3). Use of this gene-specific intronic probe reduced the complex banding pattern to the more simple form observed for other rhino species. Side-by-side comparison of the wrLH $\beta 1$ band positions with those of the Sumatran rhino, which has a single-copy LH $\beta$ gene (Fig. 3B and $\mathrm{C}$ ), reveals a high degree of conservation of restriction enzyme site locations within and flanking these two genes, indicating that they are homologous loci.

The preponderance of Southern blot lanes with only two bands for the white rhino (Fig. 1D and F) suggests the presence of only two genes; if there were three or more genes, there would be a high probability of observing more than two bands in several of the lanes. To obtain a more reliable estimate of gene-copy number, genomic titration assays were performed. Figure 4 shows the results of genomic titration Southern blot analyses in which lanes of genomic DNA digested with selected restriction enzymes were spiked with genomic equivalent standards of linearized wrLH $\beta 1$ containing plasmid. Sequence and mapping analyses (see Fig. 5 below) were used to select enzymes

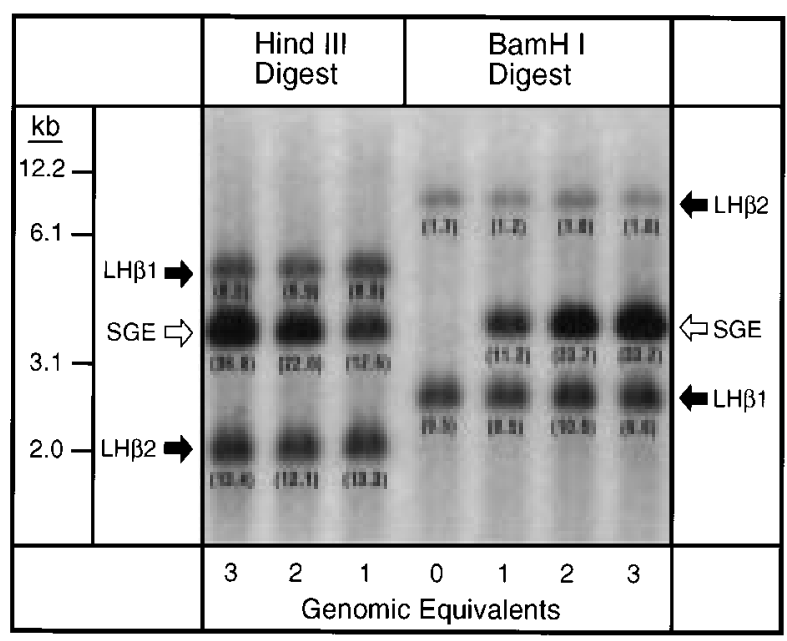

FIGURE 4. Estimation of wrLH $\beta$ gene copy number by genomic titration analysis suggests the presence of only two genes per haploid genome. Genomic blots were hybridized with full-length wrLH $\beta$ cDNA probe. Open arrows indicate bands containing standard genomic equivalents (SGE; per haploid genome) of cloned full-length wrLH $\beta 1$ gene sequence, and filled arrows indicate bands containing wrLH $\beta$ genes of genomic origin. Values from densitometric quantification are indicated in parentheses under the bands.

(HindIII and BamHI) for genomic digestion such that cleavage would not occur within the span of genomic sequence to which the homologous cDNA probe would hybridize. Total optical density unit values of each of the two HindIII bands were closest to the value obtained for the single genomic equivalent standard band, indicating two LH $\beta$ gene copies per haploid genome. For the BamHI lanes, the total optical density unit value for the lower band (wrLH $\beta 1$ ) was closest to the single genomic equivalent standard, while the value for the upper genomic band (known to contain at least one full-length wrLH $\beta 2$ copy) anomalously indicated the presence of a small fraction of one genomic equivalent. However, this upper BamHI band consistently exhibits low intensity (see also Fig. 1D and $\mathrm{F}$ ), presumably a consequence of microenvironmental blot conditions (e.g. local background DNA milieu) that are not conducive to hybridization at that lane location. Nevertheless, because the closest non-zero whole integer standard value interpolated for this band is one genomic equivalent, the BamHI genomic titration data are most consistent with the interpretation that there are probably two wrLH $\beta$ genes. While these data are persuasive that there are more than one and fewer than four genes, the possibility of a third partial or full-length LH $\beta$ 

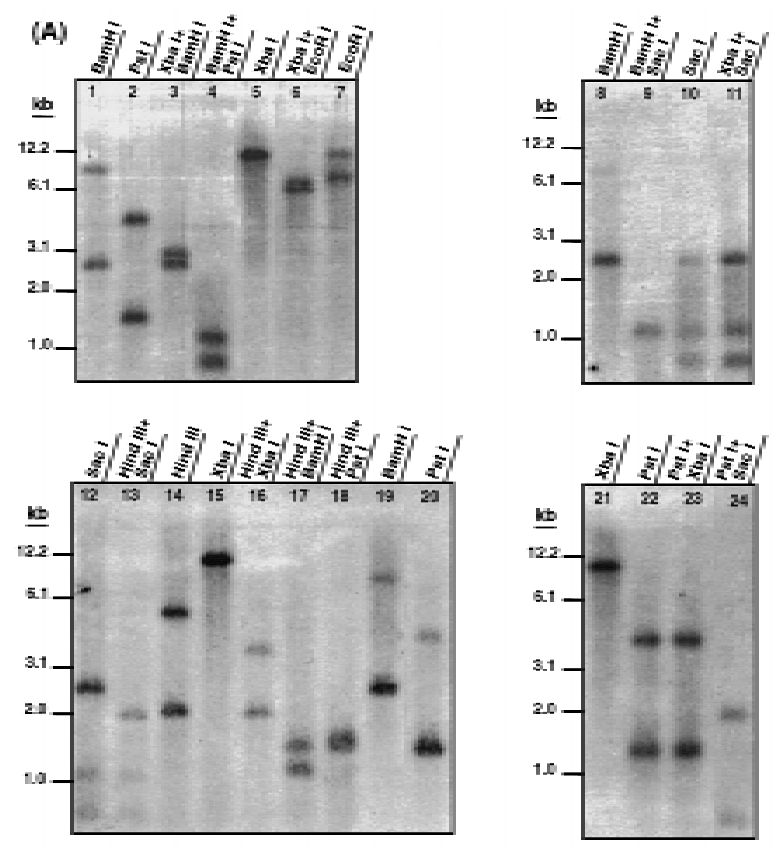

(B)
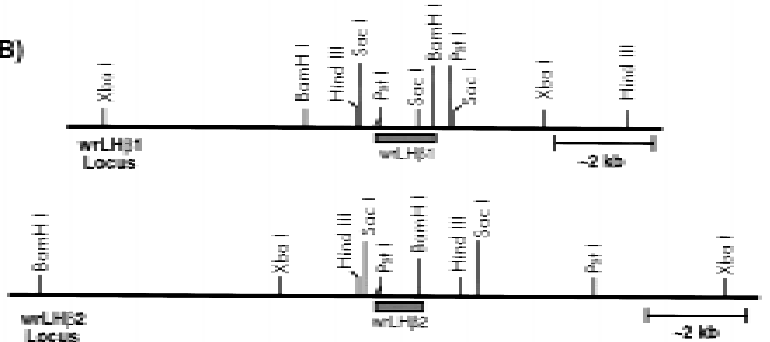

FIGURE 5. White rhino LH $\beta$ gene loci restriction-site mapping by Southern blot analysis. (A) Southern blots used to generate restriction maps (see Table 1 for estimated sizes of restriction fragments). Genomic blots were hybridized with full-length wrLH $\beta$ cDNA probe.

(B) Deduced restriction-site maps. Restriction-site mapping data show that $\mathrm{wrLH} \beta 1$ and $w \mathrm{LH} \beta 2$ reside on two non-overlapping $\sim 9 \mathrm{~kb}$ DNA fragments and are therefore not closely linked.

sequence cannot be entirely dismissed because of the semi-quantitative nature of this type of assay.

The extra-dark single band in the XbaI lane of the Southern blots in Fig. 1 ( $D$ and E) suggested that wrLH $\beta 1$ and wrLH $\beta 2$ may be closely linked within a single $\sim 9 \mathrm{~kb}$ restriction fragment, analogous to the tandem arrangement of LH $\beta$ and CG $\beta$ genes in primates. To explore this possibility further, genomic restriction-mapping studies were undertaken (Fig. 5 and Table 1). Comparisons among the three Southern blot lanes containing DNA digested with XbaI, EcoRI and XbaI+EcoRI (Fig. 5A, lanes 5, 7 and 6) ruled out the possibility

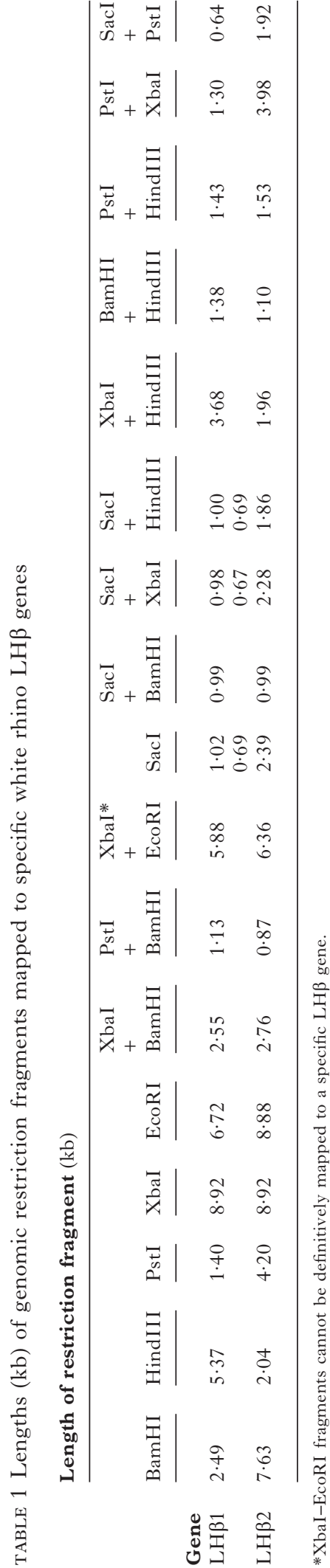

Fournal of Molecular Endocrinology (1998) 21, 19-30 
that both gene copies were contained within the single $\mathrm{XbaI}$ fragment. This conclusion is based on the finding that the sum of the fragment lengths resulting from the $\mathrm{XbaI}+\mathrm{EcoRI}$ co-digestion $(5.88 \mathrm{~kb}+6.36 \mathrm{~kb}=12 \cdot 24 \mathrm{~kb})$ is significantly greater than the $8.92 \mathrm{~kb}$ length of the entire XbaI fragment (Table 1). The experiment was repeated with the same outcome, indicating that the two genes are contained within two different $\mathrm{XbaI}$ fragments that are coincidentally the same size. Reflecting this finding, restriction-site maps are proposed for each of two distinct wrLH $\beta$-containing DNA fragments (Fig. 5B). Analysis of genomic blot restriction fragment length data (Fig. 5A and Table 1), in conjunction with gene-specific probe analysis findings (Fig. 3) and restriction-site location data derived directly from nucleotide sequencing data (Fig. 2B), revealed only one plausible linear order of restriction sites for the two LH $\beta$ loci (Fig. 5B).

The blots generated for restriction mapping provided further data supporting the contention that there are two, rather than three, genes. Sequence analysis of wrLH $\beta 1$ and wrLH $\beta 2$ genomic clones identified conserved PstI and BamHI sites within exon 1 and $3^{\prime}$-UTR respectively. Two bands of precisely the predicted sizes (differing only by the $289 \mathrm{bp}$ intron length) and of similar signal intensity were detected in the lane where DNA was co-digested with PstI and BamHI (Fig. 5, lane 4). Because only two bands were observed in this lane, if there were a third gene-containing fragment, it would be co-migrating with one of the other two genes. This in turn would lead to an increase (approximate doubling) in the relative density of one band. However, the intensities of the two closely migrating bands in the BamHI+PstI lane were consistently observed to be comparable. Bands of similar intensity were also observed in each of the other two instances where bands within the same lane migrated close to each other (Fig. 5; lane 3, XbaI+BamHI and lane 6, $\mathrm{XbaI}+\mathrm{EcoRI}$ ).

\section{DISCUSSION}

Previous studies in our laboratory revealed that the haploid genome of the Indian rhino carries a single-copy LH $\beta$ gene (Sherman et al. 1997). Because this matched the equid and consensus mammalian conditions (Bousfield et al. 1994), it was not considered likely that more than a single LH $\beta$ gene would be found in other perissodactyl species. While this prediction was accurate for Baird's tapir and Sumatran and black rhinos, evidence for multiple gene copies was discovered for the white rhino (Fig. 1), suggesting that $\mathrm{LH} \beta$ locus structure, and possibly function, have diverged along a distinctive evolutionary pathway in this species. This is the first case of LGH $\beta$ gene replication reported in a mammalian species outside the order Primates.

Although results from any one gene-copy number analysis may be questionable, evidence supporting the same estimated value was derived from several semi-quantitative experiments (Figs. 1, 4 and 5), thereby providing a greater measure of confidence that the estimate of two wrLH $\beta$ gene copies is correct. Despite the preponderance of evidence pointing to two genes, however, the existence of other partial or full-length wrLH $\beta$ gene sequence elements, or alternative allelic forms, cannot be entirely ruled out. Nevertheless, the assumption is made for the purposes of the following discussion that there are two LH $\beta$ genes, LH $\beta 1$ and LH $\beta 2$, per haploid genome in the white rhino.

Two lines of evidence indicate that gene duplication was a relatively recent mutational event. First, because only single LH $\beta$ genes are present in the other three rhino species examined, duplication did not occur until after divergence of the white rhino (genus Ceratotherium) from other rhino lineages. Indeed, morphological and molecular analysis of the family Rhinocerotidae indicate that Ceratotherium was the most recent genus to diverge (7-2.5 million years ago) during the radiation of extant rhinos which began an estimated 22 million years ago (Prothero et al. 1989, Morales \& Melnick 1994). Second, wrLH $\beta 1$ and wrLH $\beta 2$ exhibit identical coding sequences. A high degree of nucleotide sequence similarity is consistent with relatively recent divergence from a common ancestral gene. However, conservation of coding sequence can also result from concerted evolution, wherein there is a selective advantage for the co-expression of two or more homologous genes (Lewin 1997b). Either or both circumstance(s) may be operational in this case.

The consensus second intron was present in wrLH $\beta 1$ but absent in wrLH $\beta 2$ (Fig. 2). The absence of introns is a defining characteristic of a class of genomic repetitive elements called processed pseudogenes. They arise as a consequence of unintended re-integration into the eucaryotic genome of a cDNA reverse-transcribed from a host cell mRNA during a retroviral infection (Lewin 1997c). Because mRNA processing is the only known mechanism by which precise excision of introns occurs (Lewin 1997c), it is concluded that wrLH $\beta 2$ is a processed gene, with the qualification that a partially spliced ancestral 
wrLH $\beta 1$ mRNA served as template for reverse transcription.

The two wrLH $\beta$ loci would not be expected to be in close proximity because processed pseudogenes integrate randomly into the genome. Consistent with this expectation, genomic restriction-mapping analyses indicate that $w r L H \beta 1$ and $w r L H \beta 2$ reside in distinct non-overlapping $\sim 9 \mathrm{~kb} \mathrm{XbaI}$ fragments (Fig. 5). This proposed genesis and structure of white rhino $\mathrm{LH} \beta$ loci contrasts with the primate LH $\beta-C G \beta$ gene cluster-locus wherein the repeated members of the gene family are tandemly linked (Talmadge et al. 1983, Policastro et al. 1983, Graham et al. 1987, Jameson \& Lindell 1988), having evolved by a different replicative process involving unequal crossing over of adjacent DNA regions (Stark \& Wahl 1995).

A mutation must be introduced into the germline in order to be inherited. Therefore, the transcriptional event creating wrLH $\beta 1 \mathrm{mRNA}$, and hence wrLH $\beta 2$, must have occurred within a gamete or early conceptus. While there appears to be no evidence in extant species for CG $\beta$ synthesis in gametes, expression of CG $\beta$ and LH/CG $\beta$ genes by conceptus trophoblast cells is well documented in primates and equids respectively (Baird et al. 1991, Woodward et al. 1993, Hoppen 1994). Furthermore, the inner cell mass, which gives rise to germline cells, is supplemented with cells dividing from the trophoblast layer before germline differentiation (Pederson et al. 1986, Fleming 1987). Such an exchange thus constitutes a potential mechanism for CG $\beta$-producing trophoblast layer cells to mediate transfer of mRNA and/or cDNA (i.e. processed gene template) into the germline genome, a process analogous to that used in the production of stable transgenic mice using contemporary stem cell methodologies.

The consensus ungulate LH $\beta$ PCR primer used to amplify wrLH $\beta 2$ corresponds to sequence upstream of the TATA box, which in turn suggests that an LH $\beta$-like promoter sequence in wrLH $\beta 2$ extends an undetermined distance upstream of the TATA element. We have previously demonstrated that pituitary transcription of LH $\beta$ genes in the white and black rhino initiates $26 \mathrm{bp}$ downstream (nucleotide +1 in Fig. 2B) of the consensus LH $\beta$ TATA box (Sherman et al. 1997). Therefore, the homologous sequence observed between nucleotides -1 and -57 (Fig. 2B) in wrLH $\beta 2$ would not be included in cDNA derived from an mRNA transcribed under the direction of either the consensus TATA-regulated pituitary LH $\beta$ promoter or a TATA-regulated common placentalpituitary equid LH/CG $\beta$-like promoter. Taken together, the data support the contention that transcription of the wrLH $\beta 1 \mathrm{mRNA}$ that served as template for wrLH $\beta 2$ synthesis was driven by an alternative upstream promoter, thereby generating an mRNA with a lengthened TATA-containing 5 '-UTR.

What is the significance of a secondary upstream promoter site? One possible scenario is that the same retroviral infection that introduced the enzyme reverse transcriptase also induced, directly or indirectly, transcription of the wrLH $\beta 1$ gene from an anomalous upstream initiation site. Another possibility is that there were cryptic or promiscuous (i.e. non-physiological) upstream promoters that occasionally drove wrLH $\beta 1$ transcription. Finally, wrLH $\beta 1$ transcription could have been directed by a second physiologically relevant promoter located upstream of the consensus TATA-regulated promoter. Among these options, the notion of a physiological upstream promoter is particularly noteworthy because of its resemblance to the transcriptional mechanism employed by primate CG $\beta$ genes expressed in trophoblast cells of the early conceptus and placenta. In humans, CG $\beta$ gene transcription is driven by a TATA-less upstream promoter which transcribes a $350 \mathrm{bp}$ long $5^{\prime}$-UTR that includes a TATA element located in a position homologous to the functional TATA box of consensus LH $\beta$ genes. Thus full-length reverse transcripts of human CG $\beta$ mRNA would include TATA-containing LH $\beta$-like proximal promoter sequence. By analogy, the existence of an alternative upstream wrLH $\beta 1$ promoter would account for the presence of TATA-containing pituitary proximal promoter sequence in the $5^{\prime}$-UTR of wrLH $\beta 1$ mRNA, and hence also in the corresponding wrLH $\beta 2$ processed gene. It is not known how much further upstream of position - 57 wrLH $\beta 1$ like flanking sequence may be retained in wrLH $\beta 2$. Evidence that promoter homology may extend as far as the corresponding human CG $\beta$ transcriptional start site is the finding that both white rhino genes contain similarly positioned HindIII and SacI sites at approximately -400 (Fig. 5). Overall, it can be deduced that at some point in the evolutionary past an upstream promoter directed synthesis of wrLH $\beta 1$ mRNA in germline tissue, and that reverse transcription of an incompletely spliced form of this transcript produced a cDNA that re-integrated randomly into the genome, thereby creating a novel wrLH $\beta 2$ locus. It is less certain in which germline cell type(s) (gamete or early conceptus cells) upstream wrLH $\beta 1$ transcriptional initiation occurred and whether upstream transcriptional initiation was physiological or anomalous.

Although characterization of additional promoter sequence was beyond the scope of this study, it will 
be of interest to determine how much wrLH $\beta 1$ promoter sequence transmitted to wrLH $\beta 2$. Transient transfection assays using primary cultures of pituitary cells have shown that as little as $75 \mathrm{bp}$ of rat LH $\beta$ 5'-flanking sequence was sufficient to support $38 \%$ of the transcriptional activity exhibited by a $1.7 \mathrm{~kb}$ rat $\mathrm{LH} \beta$ promoter (Kim et al. 1990). If the same is true for wrLH $\beta 1$, then only a relatively small amount of $5^{\prime}$-flanking sequence carried along during the creation of wrLH $\beta 2$ would be sufficient to constitute a partially or even fully active pituitary promoter.

Re-integrated cDNA elements are typically transcriptionally and/or translationally incompetent (i.e. pseudogenes) as a consequence of the absence of promoter sequence and/or the presence of readily identifiable disruptions of regulatory or coding nucleotide sequence structure (Lewin 1997c). As revealed in the present studies, however, an undetermined length of intact proximal promoter is present in wrLH $\beta 2$, and no other structural features known to induce transcriptional or translational dysfunction have been identified. Indeed, wrLH $\beta 2$ processed gene structure is consistent with what would be predicted to constitute a functional artificial transgene construct. Hence, use of the term pseudogene to describe wrLH $\beta 2$ would be presumptuous. Accordingly, we propose the less qualified term 'processed gene' to acknowledge the unconfirmed functional status of wrLH $\beta 2$, and 'processed eugene' to designate a putative re-integrated cDNA element shown to be functional. While evidence to date indicates that wrLH $\beta 2$ may be a processed eugene, evaluation of this possibility must await experimental confirmation.

The data we present herein necessitate consideration of several options regarding extant and ancestral structure-function relationships for wrLGH $\beta$ genes (summarized in Fig. 6). The existence of a potentially active wrLH $\beta 2$ leads to three possibilities with regard to contemporary pituitary expression patterns: (1) both wrLH $\beta 1$ and wrLH $\beta 2$ are functional, (2) wrLH $\beta 1$ is functional and wrLH $\beta 2$ is a processed pseudogene, or (3) wrLH $\beta 2$ is functional and wrLH $\beta 1$ has become a pseudogene. In addition, wrLH $\beta 1$ may at present be expressed in both pituitary and germline (wrLH/CG $\beta$ ), germline only (wrCG $\beta$ ), or not at all (pseudogene). With regard to ancestral promoter function, it can be concluded that wrLH $\beta 1$ was transcriptionally active in the pituitary because this homologue corresponds to the consensus mammalian single-copy LH $\beta$ gene. It is also known that wrLH $\beta 1$ exhibited ancestral germline transcriptional activity utilizing an alternative upstream

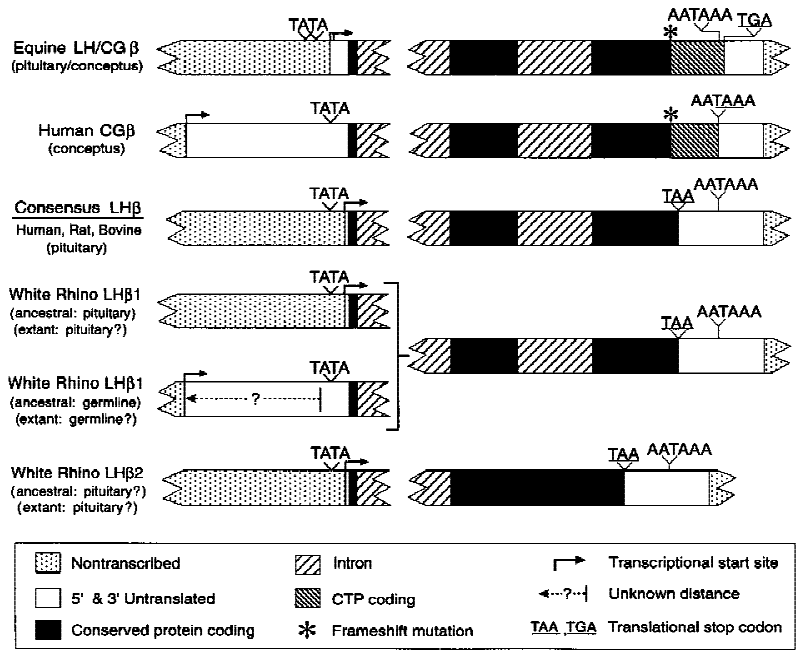

FIGURE 6. Diagram summarizing and comparing structure-function relationships of the two wrLH $\beta$ genes and LGH $\beta$ genes of other mammals. For equine, human and consensus mammalian LGH $\beta$ genes, established sites of tissue-specific expression are shown in parentheses beneath the construct label. For wrLH $\beta$ gene/promoter combinations, tissue-specific expression is further qualified in parentheses as follows: ancestral, evolutionary past; extant, present-day; ?, uncertain promoter activity for the tissue/time-frame combination indicated. See the Discussion for further details.

promoter, and that one such transcript served as template during the genesis of wrLH $\beta 2$. Finally, ancestral wrLH $\beta 2$ pituitary expression (i.e. transcriptional activation immediately after stable integration into the genome) cannot be ruled out. Neither extant nor ancestral germline expression of wrLH $\beta 2$ is postulated because of the low probability of random re-insertion downstream of sequence capable of directing germline-specific transcription.

In conclusion, the presence of two distinct and potentially functional LH $\beta$ loci in the white rhinoceros, but not other perissodactyl species, indicates recent evolutionary divergence of wrLH $\beta$ gene structure, and possibly function, relative to the consensus mammalian condition. Inclusion of homologous pituitary proximal promoter sequence in the conserved processed wrLH $\beta 2$ gene demonstrates that the ancestral wrLH $\beta 1$ gene was expressed from an alternative upstream promoter site in the gamete or early conceptus (i.e. germline cells). While germline expression of wrLH $\beta 1$ from an upstream transcriptional start site could have been spurious, it is also possible that this alternative site was (and perhaps still is) a physiologically relevant conceptus-specific promoter that functions 
in a manner analogous to hCG $\beta$ genes. It is anticipated that the findings presented in this report will provide a basis for novel comparative analyses of mammalian LH $\beta, C G \beta$ and LH/CG $\beta$ gene structure and promoter function. Furthermore, it is hoped that these studies will underpin efforts to develop a better understanding of the reproductive endocrinology of the many critically endangered species within the order Perissodactyla.

\section{ACKNOWLEDGEMENTS}

Appreciation is extended to Ms Janet Rachlow and her colleagues at Matobo National Park in Zimbabwe for providing a cryopreserved pituitary gland from a 5-year-old male southern white rhinoceros (white rhino 2), to Dr Evan Blumer and the staff at the Fossil Rim Wildlife Refuge in Texas for permitting the authors to attend the euthanasia of a 31-year-old female southern white rhinoceros (white rhino 1) for the purpose of collecting a fresh pituitary gland, and for harvesting, cryopreserving and shipping a pituitary gland from a 20 -year-old female black rhino that was subsequently euthanized, and to the San Diego Zoo for providing somatic tissues from the remainder of the perissodactyl species from which genomic DNA was purified. The authors also thank Dr Patricia Weston for her critical reading of the manuscript and Dr David Bunick for advice and technical assistance. Special gratitude is expressed to the Mark Morris Foundation for its financial and administrative assistance in funding the research through which this information was discovered (grant no 93ZO-6). Without the Foundation's support and encouragement this program of research studies would not be possible. This study is part of a thesis prepared by $\mathrm{L}$ A L towards fulfillment of the requirements for an MSc degree at the University of Illinois.

\section{REFERENCES}

Baird DD, Weinberg CR, Wilcox AJ, McConnaughey DR, Musey OI \& Collins DC 1991 Hormonal profiles of natural conception cycles ending in early unrecognized pregnancy loss. Fournal of Clinical Endocrinology and Metabolism 72 793-800.

Bo M \& Boime I 1992 Identification of the transcriptionally active genes of the chorionic gonadotropin gene cluster in vivo. Fournal of Biological Chemistry 267 3172-3184.

Bousfield GR, Perry WM \& Ward DN 1994 Gonadotropins: chemistry and biosynthesis. In The Physiology of Reproduction, edn 2, pp 1749-1792. Eds E Knobil \& JD Neill. New York: Raven Press.

Brown T 1995 Analysis of DNA sequences by blotting and hybridization. In Current Protocols in Molecular Biology, pp $2 \cdot 9 \cdot 1-2 \cdot 10 \cdot 16$. Eds FM Ausubel, R Brent, RE Kingston,
DD Moore, JG Seidman, JA Smith \& K Struhl. New York: John Wiley \& Sons.

Crawford RJ, Tregear GW \& Niall HD 1986 The nucleotide sequences of baboon chorionic gonadotropin $\beta$-subunit genes have diverged from the human. Gene 46 161-169.

Fleming TP 1987 Quantitative analysis of cell allocation to trophectoderm and inner cell mass in the mouse embryo. Developmental Biology 119 520-531.

Graham MY, Otani T, Boime I, Olson MV, Carle GF \& Chaplin DD 1987 Cosmid mapping of the human chorionic gonadotropin subunit genes by field-inversion gel electrophoresis. Nucleic Acids Research 15 4437-4448.

Gwenda JM, Bambra CS \& Tarara RP 1990 Studies with human, baboon, and vervet monkey chorionic gonadotrophins. Fournal of Medical Primatology 19 715-724.

Hearn JP, Webley GE \& Gidley-Baird AA 1991 Chorionic gonadotrophin and embryo-maternal recognition during the peri-implantation period in primates. Fournal of Reproduction and Fertility 92 497-509.

Hoppen HO 1994 The equine placenta and equine chorionic gonadotrophin: an overview. Experimental and Clinical Endocrinology 102 235-243.

Jameson JL \& Lindell CM 1988 Isolation and characterization of the human chorionic gonadotropin beta subunit (CG beta) gene cluster: regulation of transcriptionally active CG beta gene by cyclic AMP. Molecular and Cellular Biology 8 5100-5107.

Kim KE, Day KH, Howard P, Salton SRJ, Roberts JL \& Maurer RA 1990 DNA sequences required for expression of the $\mathrm{LH} \beta$ promoter in primary cultures of rat pituitary cells. Molecular and Cellular Endocrinology 74 101-107.

Lewin B $1997 a$ Genomes. In Genes, edn 6, p 646. Ed B Lewin. New York: Oxford University Press.

Lewin B $1997 b$ Gene numbers. In Genes, edn 6, pp 708-709. Ed B Lewin. New York: Oxford University Press.

Lewin B 1997c Retroviruses and retroposons. In Genes, edn 6, pp 615-616. Ed B Lewin. New York: Oxford University Press.

Morales JC \& Melnick DJ 1994 Molecular systematics of the living rhinoceros. Molecular Phylogenetics and Evolution 3 128-134.

Murphy BD \& Martinuk SD 1991 Equine chorionic gonadotropin. Endocrine Reviews 12 27-44.

Pederson RA, Wu K \& Batakier H 1986 Origin of the inner cell mass in mouse embryos: cell lineage analysis by microinjection. Developmental Biology 117 581-595.

Pierce JG \& Parsons TF 1981 Glycoprotein hormones: structure and function. Annual Review of Biochemistry $\mathbf{5 0}$ 465-495.

Policastro P, Ovitt CE, Hoshina M, Fukuoka H, Boothby MR \& Boime I 1983 The $\beta$-subunit of human chorionic gonadotropin is encoded by multiple genes. Fournal of Biological Chemistry 258 11492-11499.

Prothero DR, Guerin C \& Manning E 1989 The history of the rhinocerotoidea. In The Evolution of Perissodactyls, p 336. Eds DR Prothero \& RM Schoch. New York: Clarendon Press.

Seshagiri PB \& Hearn JP 1993 In vitro development of in vivo produced rhesus monkey morulae and blastocysts to hatched, attached, and post-attached blastocyst stages: morphology and early secretion of chorionic gonadotrophin. Human Reproduction 8 279-287.

Sherman GB, Wolfe MW, Farmerie TA, Clay CM, Threadgill DS, Sharp DC \& Nilson JH 1992 A single gene encodes the $\beta$-subunits of equine luteinizing hormone and chorionic gonadotropin. Molecular Endocrinology 6 951-959.

Sherman GB, Lund LA, Bunick D \& Winn RJ 1997 Characterization and phylogenetic significance of rhinoceros 
luteinizing hormone beta $(\mathrm{LH} \beta)$ subunit mRNA structure, cDNA sequence, and gene copy number. Gene 195 131-139.

Stark GR \& Wahl GM 1995 Gene amplification. Annual Review of Biochemistry 53 447-491.

Steinetz BG, Randolph C \& Mahoney CJ 1992 Serum concentrations of relaxin, chorionic gonadotropin, estradiol$17 \beta$, and progesterone during the reproductive cycle of the chimpanzee (Pan troglodytes). Endocrinology 130 3601-3607.

Strauss WM 1995 Preparation of genomic DNA from mammalian tissue. In Current Protocols in Molecular Biology, pp $2 \cdot 2 \cdot 1-2 \cdot 2 \cdot 3$. Eds FM Ausubel, R Brent, RE Kingston, DD Moore, JG Seidman, JA Smith, \& K Struhl. New York: John Wiley \& Sons.

Summers PM, Taylor CT \& Miller MW 1993 Requirement of inner cell mass for efficient chorionic gonadotrophin secretion by blastocysts of common marmosets (Callithrix jacchus). Fournal of Reproduction and Fertility 97 321-327.

Talmadge K, Boorstein WR \& Fiddes JC 1983 The human genome contains seven genes for the $\beta$-subunit of chorionic gonadotropin but only one gene for the $\beta$-subunit of luteinizing hormone. DNA 2 281-289.

Talmadge K, Vamvakopoulos NC \& Fiddes JC 1984 Evolution of the genes for the $\beta$-subunits of human chorionic gonadotropin and luteinizing hormone. Nature $30737-40$.

Woodward BJ, Lenton EA \& Turner K 1993 Human chorionic gonadotrophin: embryonic secretion is a time-dependent phenomenon. Human Reproduction 8 1463-1468.

REVISED MANUSCRIPT RECEIVED 16 February 1998 